\title{
The Foundation Programme application: an alternative to the Situational Judgement Test
}

This article was published in the following Dove Press journal:

Advances in Medical Education and Practice

14 October 2015

Number of times this article has been viewed

\section{Ankur Patel \\ Aaron Philip \\ Faculty of Medicine, Imperial College London, London, UK}

\section{Dear editor}

We read with great interest the article by Singagireson et al on the fairness of the Situational Judgement Test (SJT) as a method for ranking medical students applying to the UK Foundation Programme. ${ }^{1}$

The SJT assesses the applicant's approach to hypothetical, yet realistic, situations which could be encountered by a newly qualified, Foundation Year 1 (FY1) doctor. To perform well, applicants should be familiar with the roles and responsibilities of an FY1 doctor. However, as the SJT is not an assessment of clinical knowledge, revision is difficult and therefore students aiming to do well cannot necessarily rely on extensive preparation. Many would argue that this is unfair.

The lack of correlation between the performance at medical school and the performance in the SJT is also worrying. ${ }^{2}$ We strongly believe that students who excel in medical school should excel as doctors since the curricula of all UK medical schools are individually approved by the General Medical Council - the organization which sets standards for doctors and oversees their education and training. Accordingly, we believe that the SJT should be replaced by an assessment that correlates more strongly with performance in medical school. This is likely to be the one evaluating the clinical knowledge of the candidates. We find it difficult to understand why this would pose a problem as the SJT is essentially used as a tool to compare medical students across the country. An additional advantage of using such an assessment is that students are better able to prepare for it.

Another alternative to the SJT is to interview and subsequently score all Foundation Programme applicants. However, due to the vast number of candidates every year, this is unlikely to be practical.

Nevertheless, we feel that it is important for all medical students to have good insight into the role of an FY1 doctor and therefore an assessment similar to the SJT could perhaps be integrated into undergraduate medical education as a summative examination.

\section{Disclosure}

The authors report no conflicts of interest in this communication.

\section{References}

1. Singagireson S, Ramjeeawon N, Ravindra S, Shah N, Singh B. Is it fair for a junior doctor's deanery to be largely based on one test: a student's perspective. Adv Med Educ Pract. 2015;6:499-500.

2. Simon E, Walsh K, Paterson-Brown F, Cahill D. Does a high ranking mean success in the Situational Judgement Test? Clin Teach. 2015;12(1):42-45. 
Dove Medical Press encourages responsible, free and frank academic debate. The content of the Advances in Medical Education and Practice 'letters to the editor' section does not necessarily represent the views of Dove Medical Press, its officers, agents, employees, related entities or the Advances in Medical Education and Practice editors. While all reasonable steps have been taken to confirm the content of each letter, Dove Medical Press accepts no liability in respect of the content of any letter, nor is it responsible for the content and accuracy of any letter to the editor.

Advances in Medical Education and Practice

Dovepress

\section{Publish your work in this journal}

Advances in Medical Education and Practice is an international, peerreviewed, open access journal that aims to present and publish research on Medical Education covering medical, dental, nursing and allied health care professional education. The journal covers undergraduate education, postgraduate training and continuing medical education including emerging trends and innovative models linking education, research, and health care services. The manuscript management system is completely online and includes a very quick and fair peer-review system. Visit http://www.dovepress.com/testimonials.php to read real quotes from published authors.

Submit your manuscript here: http://www.dovepress.com/advances-in-medical-education-and-practice-journal 